\title{
Exploring the Utility of Partial Cytochrome $c$ Oxidase Subunit 1 for DNA Barcoding of Gobies
}

\author{
Hyung-Bae Jeon ${ }^{1}$, Seung-Ho Choi ${ }^{2}$, Ho Young Suk ${ }^{1, *}$ \\ ${ }^{1}$ Department of Life Sciences, Yeungnam University, Gyeongsan 712-749, Korea \\ ${ }^{2}$ Institute of Biodiversity Research, Jeonju 561-211, Korea
}

\begin{abstract}
Gobiids are hyperdiverse compared with other teleost groups, with about 2,000 species occurring in marine, freshwater, and blackish habitats, and they show a remarkable variety of morphologies and ecology. Testing the effectiveness of DNA barcodes on species that have emerged as a result of radiation remains a major challenge in evolutionary biology. Here, we used the cytochrome $c$ oxidase subunit 1 (COI) sequences from 144 species of gobies and related species to evaluate the performance of distance-based DNA barcoding and to conduct a phylogenetic analysis. The average intra-genus genetic distance was considerably higher than that obtained in previous studies. Additionally, the interspecific divergence at higher taxonomic levels was not significantly different from that at the intragenus level, suggesting that congeneric gobies possess substantial interspecific sequence divergence in their COI gene. However, levels of intragenus divergence varied greatly among genera, and we do not provide sufficient evidence for using COI for cryptic species delimitation. Significantly more nucleotide changes were observed at the third codon position than that at the first and the second codons, revealing that extensive variation in COI reflects synonymous changes and little protein level variation. Despite clear signatures in several genera, the COI sequences did resolve genealogical relationships in the phylogenetic analysis well. Our results support the validity of COI barcoding for gobiid species identification, but the utilization of more gene regions will assist to offer a more robust gobiid species phylogeny.
\end{abstract}

Keywords: cytochrome c oxidase subunit 1, barcoding, phylogeny, Gobiidae, Gobioidei

\section{INTRODUCTION}

Gobies (family Gobiidae; suborder Gobioidei) are incomparable among vertebrates in their capacity to adapt and diversify, which has led to adaptive radiation and rapid speciation (Zander, 2011). Gobiid fishes are hyperdiverse compared with other teleost groups, with approximately 2,000 species in 210 genera occurring in marine, freshwater, and blackish habitats. These fish show remarkable morphological and ecological variety (Nelson, 2006; Zander, 2011). Gobiid fishes are globally distributed (Nelson, 2006) and frequently represent a dominant component of coral reefs and coastal fish communities throughout much of their range, accounting for $>50 \%$ of the energy flow in some coral reef habitats (Herler et al., 2011). Despite their evolutionary and ecological importance, the phylogenetic relationships among species within Gobiidae and their location within Gobioidei are still poorly understood (Murdy, 1989; Parenti and Thomas, 1998; Thack- er and Schaefer, 2000; Larson, 2001). To date, the classification of gobies still remains largely reliant on external morphology (Pezold, 1993; Akihito et al., 2000; Nelson, 2006), and diagnostic characters separating species are subtle and problematic.

Molecular biology has contributed to addressing taxon identification and phylogenetic relationship questions. Mitochondrial DNA (mtDNA) markers have historically formed the core of most molecular systematic analyses and are still the most widely used for reconstructing phylogeny (Brown et al., 1979; Moore, 1995; Johns and Avise, 1998); this is probably due to their single copy nature and relative ease of sequencing (Moore, 1995). Genetic divergence is also enhanced by the higher rate of sequence evolution in vertebrate mtDNA compared to that of nuclear coding regions (Johns and Avise, 1998). However, the choice of a suitable gene is crucial for identification and phylogenetic reconstruction among closely related species (Brown et al., 1979; Moore,

\footnotetext{
(C) This is an Open Access article distributed under the terms of the Creative Commons Attribution Non-Commercial License (http://creativecommons.org/ licenses/by-nc/3.0/) which permits unrestricted non-commercial use, distribution, and reproduction in any medium, provided the original work is properly cited.

*To whom correspondence should be addressed

Tel: 82-53-810-2379, Fax: 82-53-810-4618

E-mail: hsuk@ynu.ac.kr 
1995; Johns and Avise, 1998), because different parts of the mtDNA genome evolve at different rates (Avise and Ellis, 1986; Roques et al., 2006).

Mitochondrial cytochrome oxidase subunit I (COI) could serve as a rapid and reliable barcoding marker for identifying species and for discovering new species across the entire animal kingdom (Hebert et al., 2003). Although skepticism has frequently been expressed (Ebach and Holdrege, 2005; Will et al., 2005), DNA barcoding based on COI has been successful to identify species across a wide array of taxa over the last decade (e.g., Hebert et al., 2004; Clare et al., 2007; Hubert et al., 2008; Feng et al., 2011). A clear gap should exist between intra- and interspecific COI sequence divergence with about a 20-fold difference for DNA barcoding to be perfectly effective in delimitating species (Hebert et al., 2003). A standard sequence threshold can be projected to outline species boundaries by employing this barcoding gap. However, utilizing such a threshold value may be challenging, particularly when attempts do not include numerous specimens, such as for critically endangered taxa.

Only a few studies have addressed gobioid interrelationships based on molecular data (e.g., Akihito et al., 2000; Wang et al., 2001; Thacker, 2003, 2009; Thacker and Hardman, 2005). These studies used different taxon and nucleotide sampling methods. Yet, testing the effectiveness of COI DNA barcodes on species that have emerged as a result of radiation, such as gobies, remains a major challenge in evolutionary biology. Here, we sequenced the COI of 48 species collected from South Korea (Table 1) to evaluate the performance of distance-based DNA barcoding for phylogenetic analyses. We specifically aimed to provide novel data on a comparison of pairwise divergence levels among species in the same genus vs. species in different genera. GenBank sequences were also included in the analyses to use a dataset with large taxonomic coverage $(n=144$ species $)$ (Table 2).

\section{MATERIALS AND METHODS}

\section{Sample collection}

Fish were collected using seine and dip nets from January to November 2011 from 21 sites across freshwater systems, coastal areas, and the ocean near South Korea (Table 1). Specimens were identified based on morphological characters. Entire bodies of all individuals were preserved in $95 \%$ ethanol, and 44 nominal species were sequenced for COI gene fragments.

\section{DNA isolation, amplification, and sequencing}

We used the Wizard Genomic DNA purification kit (Promega,
Madison, WI, USA) to extract genomic DNA from the right pectoral fin of each fish specimen. The COI was amplified using gobiid-specific primers: GOBYF7558 (forward) 5'TTT GCW ATT ATG GCW GGA TTT G-3' and GOBYB 8197 (reverse) 5'-ATT ATT AGG GCG TGG TCG TGG-3' (Thacker, 2003) and COI fish universal primers, FF2d (forward) 5'-TTC TCC ACC AAC CAC AAR GAY ATY GG$3^{\prime}$ and FF1d (reverse) 5'-CAC CTC AGG GTG TCC GAA RAA YCA RAA-3' (Ivanova et al., 2007). Each polymerase chain reaction (PCR) amplification was carried out in a 50 $\mu \mathrm{L}$ reaction volume composed of $\sim 75 \mathrm{ng}$ DNA extract, 0.25 $\mathrm{mM}$ of each deoxynucleotide, $0.25 \mathrm{mM}$ of each forward and reverse primer, $3 \mathrm{mM} \mathrm{MgCl}, 1 \times \mathrm{PCR}$ buffer, and 0.25 units of Taq DNA polymerase (Solgent, Daejeon, Korea). GenePro (BIOER) was used to amplify the COI with the following program: $94^{\circ} \mathrm{C}$ for $10 \mathrm{~min}, 35$ cycles of $30 \mathrm{~s}$ at $94^{\circ} \mathrm{C}, 30 \mathrm{~s}$ at $54^{\circ} \mathrm{C}$ (for GOBYF7558-GOBYB8197) and $52^{\circ} \mathrm{C}$ (for FF2dFF1d), $30 \mathrm{~s}$ at $72^{\circ} \mathrm{C}$ and final elongation at $72^{\circ} \mathrm{C}$ for $10 \mathrm{~min}$. PCR products were loaded on $1 \%$ agarose gels containing $0.003 \%$ ethidium bromide and visualized using the GelDocIt TM Imaging System (UVP). Amplifications were considered successful when a expected sized band was observed on the agarose gel. PCR products were cleaned using a PCR purification kit (Solgent). The COI was sequenced directly using the BigDye-Terminator V3.1 kit (Applied Biosystems, Foster City, CA, USA) and an ABI3730XL sequencer at Genotech (Daejeon, Korea).

\section{Sequence data analyses}

Complementary DNA sequences were assembled using the Bioedit 5.0.9 sequence-editing software (Hall, 1999). Sequences were aligned using Clustal X 2.0 default settings (Larkin et al., 2007). Alignments were translated to amino acids under the vertebrate mitochondrial option using MEGA 5 (Tamura et al., 2011) to detect frameshift mutations and premature stop codons, which may indicate the presence of pseudogenes. The Genbank accession numbers of newly determined sequences were JX679021-JX679066 and are listed in Table 1. Genetic distances were calculated to quantify sequence divergences among species using both $p$ distance and Kimura two-parameter (K2P) models (1,000 bootstrapping) (Kimura, 1980), as implemented in MEGA. Rates of synonymous and nonsynonymous substitutions were also calculated with MEGA using both standard and modified (at 1.4 standard errors with 1,000 bootstrapping samples) NeiGojobori models (Nei and Gojobori, 1986; Nei and Kumar, 2000). Genetic distances were calculated at intrageneric, intrasubfamilial, intrafamilial, and interfamilial levels. Altogether, 10,296 pairwise distances were compared in this study. The degree of sequence conservation per site, $R_{\text {seq, }}$, was defined as $R_{\text {seq }}=2-\left(-\sum p \log _{2} p\right)$ (Ward and Holmes, 2007), 


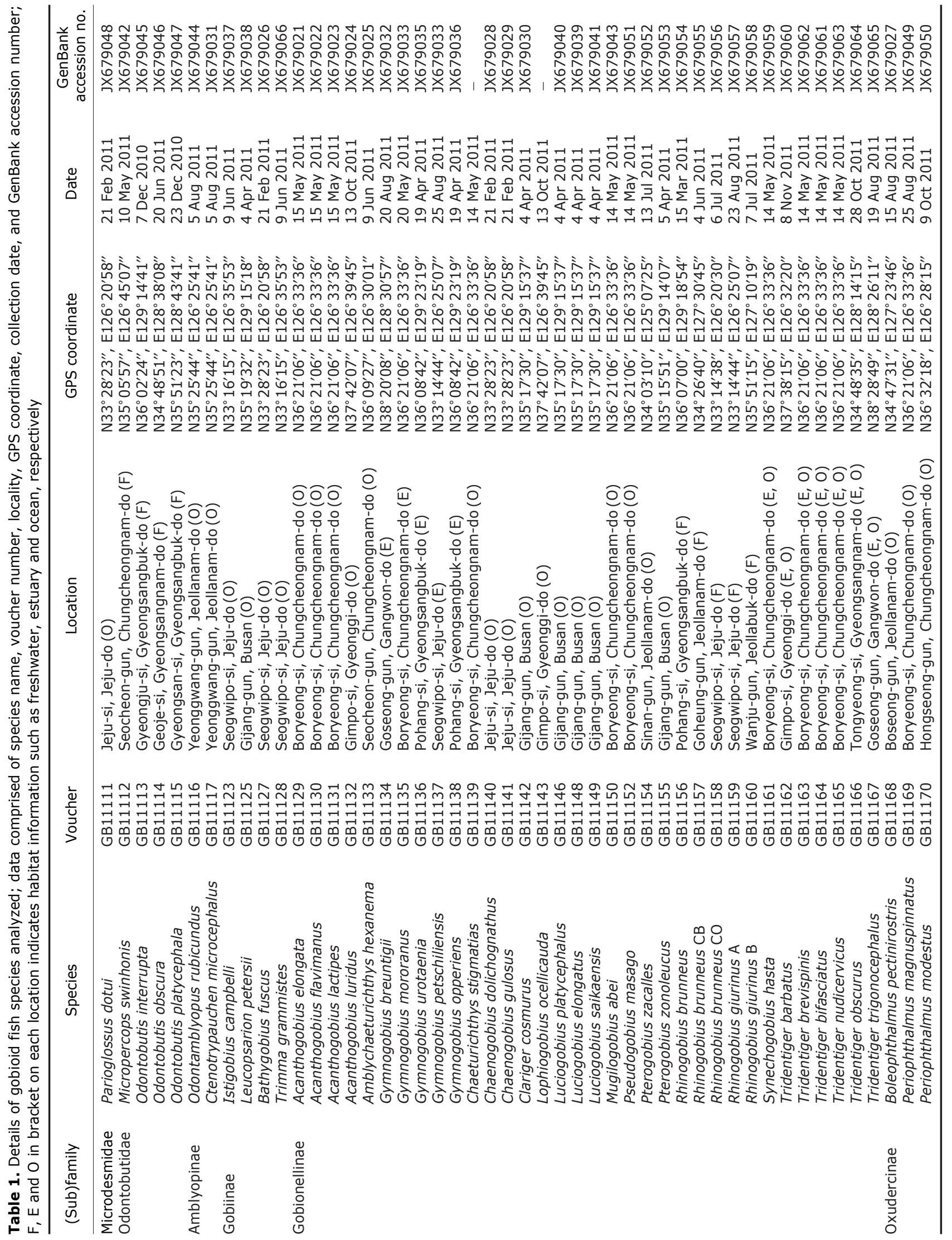


Table 2. List of reference species used in this study

\begin{tabular}{|c|c|c|c|}
\hline (Sub)family & Species & Reference & $\begin{array}{c}\text { GenBank } \\
\text { accession no. }\end{array}$ \\
\hline Odontobutidae & Perccottus glenii & Thacker and Hardman (2005) & AY722171 \\
\hline \multirow[t]{2}{*}{ Rhyacichthyidae } & Protogobius attiti & Keith et al. (2011) & HQ639032 \\
\hline & Rhyacichthys guilberti & Keith et al. (2011) & HQ639030 \\
\hline \multirow[t]{3}{*}{ Benthophilinae } & Neogobius melanostomus & Unpublished & HQ960511 \\
\hline & Proterorhinus marmoratus & Hubert et al. (2012) & EU524305 \\
\hline & Proterorhinus semilunaris & Unpublished & HQ961006 \\
\hline \multirow[t]{53}{*}{ Gobiinae } & Amblyeleotris aurora & Unpublished & HQ561508 \\
\hline & Amblyeleotris guttata & Steinke et al. (2009) & FJ582710 \\
\hline & Amblyeleotris steinitzi & Steinke et al. (2009) & FJ582712 \\
\hline & Amblyeleotris wheeleri & Unpublished & HQ561506 \\
\hline & Amblygobius decussatus & Steinke et al. (2009) & FJ582722 \\
\hline & Amblygobius phalaena & Hubert et al. (2012) & JQ431409 \\
\hline & Asterropteryx ensifera & Hubert et al. (2012) & JQ431470 \\
\hline & Asterropteryx semipunctata & Hubert et al. (2012) & JQ431471 \\
\hline & Bathygobius coalitus & Hubert et al. (2012) & JQ431479 \\
\hline & Bathygobius cocosensis & Hubert et al. (2012) & JQ431480 \\
\hline & Bathygobius cotticeps & Hubert et al. (2012) & JQ431482 \\
\hline & Bathygobius curacao & Weigt et al. (2012) & JQ839961 \\
\hline & Bathygobius lacertus & Weigt et al. (2012) & JQ839962 \\
\hline & Bathygobius laddi & Unpublished & JF492946 \\
\hline & Bathygobius mystacium & Weigt et al. (2012) & JQ839963 \\
\hline & Bathygobius soporator & Tornabene et al. (2010) & HM748425 \\
\hline & Caffrogobius caffer & Unpublished & HQ945885 \\
\hline & Coryphopterus tortugae & Weigt et al. (2012) & JQ842827 \\
\hline & Croilia mossambica & Unpublished & HQ561481 \\
\hline & Cryptocentrus cryptocentrus & Unpublished & HQ561467 \\
\hline & Cryptocentrus leptocephalus & Steinke et al. (2009) & FJ583296 \\
\hline & Cryptocentrus pavoninoides & Steinke et al. (2009) & FJ583298 \\
\hline & Elacatinus evelynae & Steinke et al. (2009) & FJ583388 \\
\hline & Elacatinus oceanops & Steinke et al. (2009) & FJ583389 \\
\hline & Eviota afelei & Thacker (2003) & AF391391 \\
\hline & Eviota disrupta & Leray et al. (2012) & JN107907 \\
\hline & Eviota distigma & Hubert et al. (2012) & JQ349971 \\
\hline & Eviota indica & Hubert et al. (2012) & JQ349972 \\
\hline & Eviota prasina & Hubert et al. (2012) & JQ349973 \\
\hline & Favonigobius exquisitus & Thacker et al. (2011) & HQ909465 \\
\hline & Fusigobius signipinnis & Steinke et al. (2009) & FJ583414 \\
\hline & Glossogobius aureus & Aquino et al. (2011) & HQ682689 \\
\hline & Glossogobius callidus & Steinke et al. (2009) & JF493535 \\
\hline & Gobiodon ceramensis & Steinke et al. (2009) & FJ583428 \\
\hline & Gobiodon histrio & Steinke et al. (2009) & FJ583450 \\
\hline & Gobiodon okinawae & Steinke et al. (2009) & FJ583454 \\
\hline & Gobiodon quinquestrigatus & Hubert et al. (2012) & JQ431768 \\
\hline & Gobiopterus lacustris & Aquino et al. (2011) & HQ682693 \\
\hline & Gobius bucchichi & Unpublished & JF935258 \\
\hline & Gobius cruentatus & Unpublished & JF935263 \\
\hline & Istigobius decoratus & Steinke et al. (2009) & JF493692 \\
\hline & Istigobius rigilius & Thacker et al. (2011) & HQ536672 \\
\hline & Knipowitschia caucasica & Triantafyllidis et al. (2011) & HQ600736 \\
\hline & Nes longus & Weigt et al. (2012) & JQ841296 \\
\hline & Paragobiodon lacunicolus & Steinke et al. (2009) & FJ583828 \\
\hline & Pomatoschistus tortonesei & Unpublished & FJ751922 \\
\hline & Priolepis cincta & Hubert et al. (2012) & $\mathrm{JQ350251}$ \\
\hline & Priolepis compita & Hubert et al. (2012) & JQ432034 \\
\hline & Priolepis eugenius & Thacker (2003) & AF391329 \\
\hline & Priolepis hipoliti & Thacker et al. (2011) & HQ909484 \\
\hline & Priolepis inhaca & Hubert et al. (2012) & JQ432036 \\
\hline & Priolepis semidoliata & Hubert et al. (2012) & JQ432038 \\
\hline & Priolepis squamogena & Hubert et al. (2012) & JQ432040 \\
\hline
\end{tabular}


Table 2. Continued

\begin{tabular}{|c|c|c|c|}
\hline (Sub)family & Species & Reference & $\begin{array}{c}\text { GenBank } \\
\text { accession no. }\end{array}$ \\
\hline \multirow[t]{14}{*}{ Gobiinae } & Priolepis triops & Hubert et al. (2012) & JQ432042 \\
\hline & Pycnomma roosevelti & Unpublished & GU224480 \\
\hline & Rhinogobiops nicholsii & Unpublished & JN582118 \\
\hline & Trimma caesiura & Thacker (2009) & EU381039 \\
\hline & Trimma macrophthalma & Hubert et al. (2012) & JQ350401 \\
\hline & Trimma mendelssohni & Hubert et al. (2012) & JQ350407 \\
\hline & Trimma milta & Hubert et al. (2012) & JQ432200 \\
\hline & Valenciennea helsdingenii & Steinke et al. (2009) & FJ584201 \\
\hline & Valenciennea longipinnis & Steinke et al. (2009) & FJ584202 \\
\hline & Valenciennea muralis & Steinke et al. (2009) & FJ584203 \\
\hline & Valenciennea puellaris & Steinke et al. (2009) & FJ584212 \\
\hline & Valenciennea sexguttata & Steinke et al. (2009) & FJ584224 \\
\hline & Valenciennea strigata & Unpublished & HQ945877 \\
\hline & Valenciennea wardii & Steinke et al. (2009) & FJ584240 \\
\hline \multirow[t]{13}{*}{ Gobionellinae } & Awaous aeneofuscus & Unpublished & HQ945950 \\
\hline & Awaous melanocephalus & Aquilino et al. (2011) & HQ654674 \\
\hline & Ctenogobiops tangaroai & Steinke et al. (2009) & FJ583310 \\
\hline & Ctenogobius saepepallens & Weigt et al. (2012) & JQ840025 \\
\hline & Gnatholepis cauerensis & Unpublished & HQ561511 \\
\hline & Gnatholepis thompsoni & Weigt et al. (2012) & JQ840079 \\
\hline & Gobioides broussonnetii & April et al. (2011) & JN026727 \\
\hline & Gobionellus oceanicus & Weigt et al. (2012) & JQ841902 \\
\hline & Lethops connectens & Unpublished & GU440372 \\
\hline & Oligolepis acutipennis & Aquilino et al. (2011) & HQ654730 \\
\hline & Oligolepis keiensis & Unpublished & HQ945926 \\
\hline & Stenogobius polyzona & Unpublished & HQ945939 \\
\hline & Typhlogobius californiensis & Unpublished & GU440562 \\
\hline \multirow[t]{2}{*}{ Oxudercinae } & Scartelaos histophorus & Unpublished & FJ238032 \\
\hline & Taenioides sp. & Steinke et al. (2009) & FJ584167 \\
\hline \multirow[t]{8}{*}{ Sicydiinae } & Akihito vanuatu & Keith et al. (2011) & HQ639065 \\
\hline & Cotylopus rubiripinnis & Keith et al. (2011) & HQ639038 \\
\hline & Lentipes armatus & Keith et al. (2011) & HQ639070 \\
\hline & Sicydium punctatum & Keith et al. (2011) & HQ639050 \\
\hline & Sicyopterus lagocephalus & Hubert et al. (2012) & JQ432152 \\
\hline & Sicyopterus pugnans & Hubert et al. (2012) & JQ432154 \\
\hline & Sicyopus chloe & Keith et al. (2011) & HQ639058 \\
\hline & Stiphodon elegans & Hubert et al. (2012) & JQ432172 \\
\hline
\end{tabular}

where $p$ is the observed frequency of each base at a particular position and the maximal degree of conservation was 2 , which was achieved when all nucleotides at a particular site in the 144 species were the same.

A Bayesian inference (BI) tree was established using MrBayes 3.1.2 (Ronquist and Huelsenbeck, 2003) with two outgroup species from the Family Rhyacichthydae, Protogobius attiti and Ryacichthys guilberti. The best-fit model of DNA sequence evolution was chosen using ModelTest 3.8 (Posada and Crandall, 1998) and Akaike information criteria; the chosen model was GTR $+\mathrm{I}+\mathrm{G}$. The analysis was run for 10 million generations with sampling of one tree every 500 generations. Two independent Markov Chain Monte Carlo runs were conducted simultaneously. The first 1,000 trees of each run were discarded as burn-in.

\section{RESULTS}

The COI genes of each species were confidently aligned, and the equivocal bases at each end were trimmed to yield a final sequence of $542 \mathrm{bp}$. No indels were detected. Translation of the sequences did not reveal frame-shift mutations or premature stop codons, confirming that our amplified fragments were functional. Among the 542 nucleotide positions, 245 were polymorphic, and 230 were parsimony informative. The proportion of T, C, A, and G bases for all 144 sequences was $30.5 \%, 28.1 \%, 23.1 \%$, and $18.2 \%$, respectively. The GC content was relatively higher at the first codon base $(56.3 \%)$ than that at the second $(43.1 \%)$ or third $(39.6 \%)$. The degree of conservation $\left(R_{\text {seq }}\right)$ was calculated for each base of the 542 nucleotides; the most common and maximum value was 2 , which was achieved when all nucleotides at a particular site 
Table 3. Estimated evolutionary parameters $(\times 100)$ for the nucleotide substitutions in the cytochrome oxidase $c$ subunit 1 (COI) barcoding region from 144 gobioid fish species

\begin{tabular}{|c|c|c|c|c|c|c|c|}
\hline \multirow{2}{*}{\multicolumn{2}{|c|}{ Genetic distance }} & \multicolumn{2}{|c|}{ All fish } & \multicolumn{2}{|c|}{ Gobiinae } & \multicolumn{2}{|c|}{ Gobionellinae } \\
\hline & & Mean & SD & Mean & SD & Mean & SD \\
\hline \multicolumn{8}{|c|}{ Codon nucleotide position } \\
\hline \multirow[t]{4}{*}{$p$ distance } & First & 5.51 & 1.63 & 5.45 & 2.05 & 5.21 & 2.06 \\
\hline & Second & 0.18 & 0.15 & 0.28 & 0.47 & 0.02 & 0.11 \\
\hline & Third & 54.31 & 3.61 & 55.49 & 5.19 & 50.19 & 7.05 \\
\hline & Overall & 19.94 & 1.66 & 20.34 & 2.10 & 18.42 & 2.69 \\
\hline \multirow[t]{4}{*}{$\mathrm{K} 2 \mathrm{P}$ distance } & First & 6.23 & 2.09 & 6.14 & 2.53 & 5.85 & 2.52 \\
\hline & Second & 0.18 & 0.15 & 0.28 & 0.48 & 0.02 & 0.11 \\
\hline & Third & 403.10 & 439.15 & 499.53 & 552.80 & 240.11 & 145.15 \\
\hline & Overall & 28.18 & 4.06 & 29.06 & 4.05 & 25.34 & 4.42 \\
\hline \multicolumn{8}{|c|}{ Synonymous and nonsynonymous distances } \\
\hline \multirow[t]{3}{*}{ Nei-Gojobori (N-G) } & Synonymous & 71.91 & 6.98 & 73.41 & 6.77 & 66.95 & 9.32 \\
\hline & Nonsynonymous & 1.64 & 0.94 & 1.72 & 0.99 & 1.29 & 0.83 \\
\hline & $d_{\mathrm{N}} / d_{\mathrm{S}}$ & 0.02 & 0.00 & 0.02 & 0.00 & 0.02 & 0.00 \\
\hline \multirow{3}{*}{ Modified N-G } & Synonymous & 62.78 & 6.06 & 64.06 & 5.88 & 58.44 & 8.11 \\
\hline & Nonsynonymous & 1.73 & 1.00 & 1.81 & 1.05 & 1.36 & 0.88 \\
\hline & $d_{\mathrm{N}} / d_{\mathrm{S}}$ & 0.03 & 0.00 & 0.03 & 0.00 & 0.02 & 0.00 \\
\hline
\end{tabular}

$\mathrm{K} 2 \mathrm{P}$, Kimura-2-parameter.

of the 144 species were the same. Every third codon base was highly variable with a 0.64 mean $R_{\text {seq. }}$ The first (1.72) and the second codon bases (1.98) were nearly monomorphic. Nucleotide genetic distance parameters, $p$ and K2P distance, also showed an almost zero rate of substitution for second nucleotide positions, with the first position being an order of magnitude higher and the third position being unparalleled among them (Table 3). The rate of synonymous substitutions was much higher than the rate of nonsynonymous substitutions (Table 3).

Three species could not be separated using the COI sequence analysis, including Chaenogobius gulosus (Gobionellinae), Chaeturichthys stigmatias (Gobionellinae), and Lophiogobius ocellicauda (Gobiinae). The C. gulosus sequence was highly similar to those of other congeneric species, as expected, whereas the C. stigmatias and L. ocellicauda results were very surprising. Multiple specimens of these species should be extensively analyzed in a future study to check the genetic divergence among these species; thus, those sequences were not deposited in GenBank. The average diversity among 142 haplotypes $\left(H_{\mathrm{d}}\right)$ was $0.999 \pm 0.001$ (mean \pm standard deviation), and the average nucleotide diversity $(\pi)$ was 0.199 \pm 0.002 . Twenty-six genera were represented by two or more species. Levels of intragenus divergence were generally high (Table 4) but varied greatly among genera. For example, the average within-genus divergence of Awaous, Eviota, and Trimma was $29.85 \%, 29.13 \%$, and $28.71 \%$, respectively, which was larger than that of overall interspecific divergence. These values were considerably larger than those of Amblygobius, Asterropteryx and Rhinogobius $(9.76 \%, 9.87 \%$, and
Table 4. Mean genetic divergences for the cytochrome oxidase $c$ subunit 1 (COI) nucleotide sequences ( $p$ and Kimura-2-parameter [K2P] distances) among 144 gobioid species

\begin{tabular}{lrrrrrrrr}
\hline \multirow{2}{*}{ Taxonomic level } & \multicolumn{3}{c}{$p$ distance $(\times 100)$} & & \multicolumn{3}{c}{ K2P distance $(\times 100)$} \\
\cline { 2 - 3 } \cline { 6 - 8 } \cline { 6 - 8 } & Mean & Min & Max & & Mean & Min & Max \\
\hline Within-genus & 15.63 & 0.18 & 23.80 & & 20.87 & 0.19 & 36.13 \\
Within-subfamily & 19.69 & 9.20 & 26.20 & & 27.87 & 0.19 & 41.44 \\
Within-family & 20.05 & 6.83 & 26.94 & & 28.35 & 0.94 & 44.53 \\
Among-family & 20.18 & 10.89 & 25.83 & & 28.56 & 13.27 & 41.06 \\
\hline
\end{tabular}

Four taxonomic levels are represented such as within-genus, within-subfamily, within-family, and among-family.

$10.74 \%$, respectively). Mean interspecific divergences at higher taxonomic levels were slightly larger than that at the intragenus level, resulting in large overlaps among levels (Table 4). As roughly $90 \%$ of all gobiid fishes are either in Gobiinae or Gobionellinae, these two subfamilies were compared for nucleotide substitution rate (Table 3). Species from Gobiinae were consistently higher than Gobionelline fishes in every parameter estimated (Table 3 ).

Our phylogenetic data provide little evidence to support the previous claims at the generic and higher taxonomic levels, based on phenetic analyses. Several species did not cluster into their respective groups, and the BI tree failed to correctly identify some genera or subfamilies (Fig. 1). For example, Tridentiger barbatus (Gobiinellinae) clustered into the Asterropteryx clade (Gobiinae) with high nodal support rather than with other species of Tridentiger. Pterogobius zacalles clustered with Acanthogobius, whereas P. zonoleucus formed a monophyletic group with the Rhinogobius brun- 


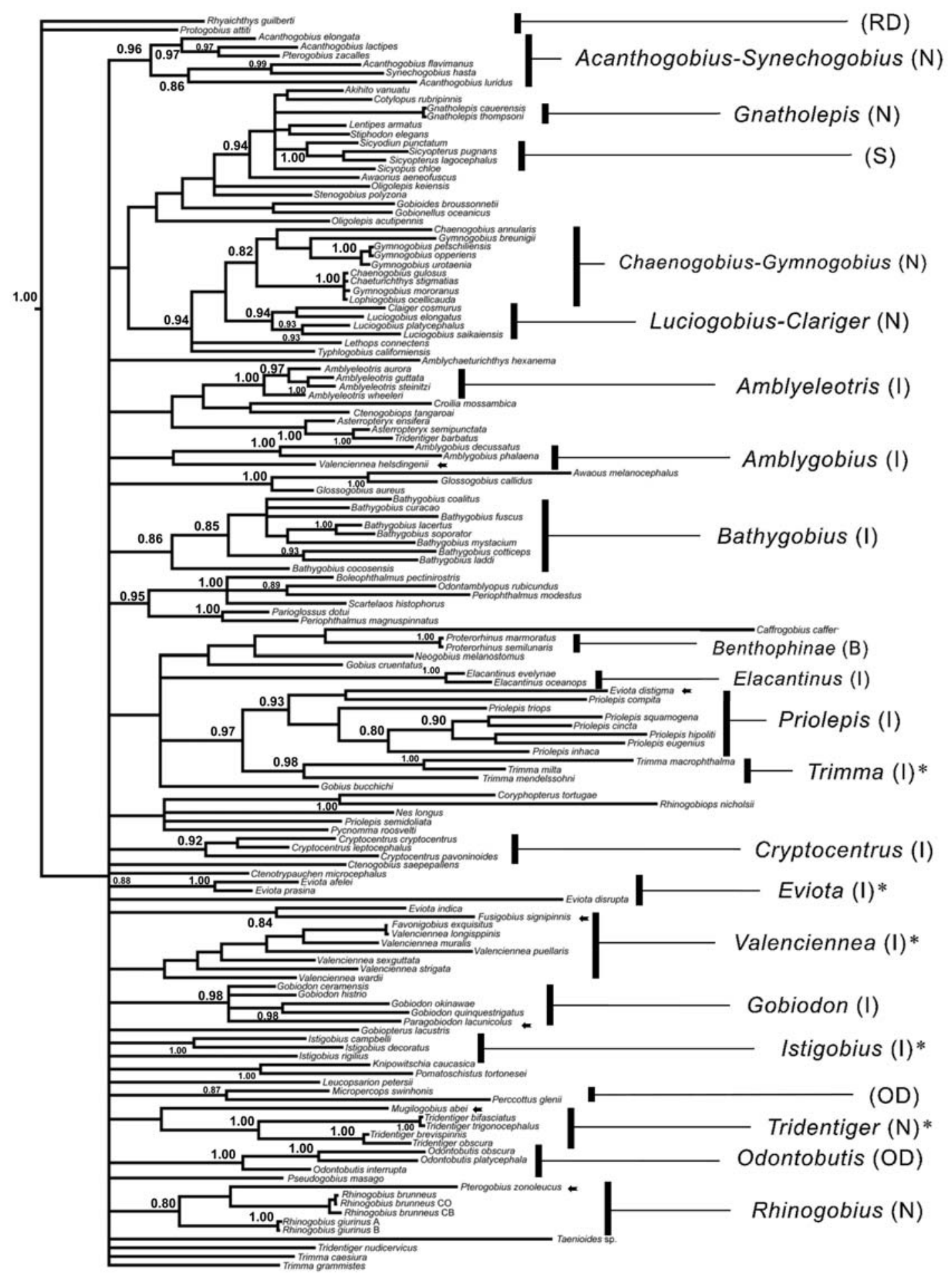

Fig. 1. Molecular phylogeny of Gobioidei based on Bayesian inference from 542 bp of the mitochondrial cytochrome oxidase $c$ subunit 1 (COI) gene with two outgroup species from the Family Rhyacichthyidae: Protogobius attiti and Rhyacichthys guilberti. Under the chosen model, GTR $+\mathrm{I}+\mathrm{G}$, analysis was run for 10 million generations with sampling of one tree every 500 generations. Numbers above branches indicate posterior probabilities $(>0.8)$. Abbreviations in brackets on the right side indicate higher taxonomic names (subfamily and family) in current usage, including Amblyopinae (A), Benthophilinae (B), Gobiinae (I), Gobionellinae (N), Oxudercinae $(O)$, Sicydiinae (S), Microdesmidae (MD), Odontobutidae (OD), and Rhyacichthyidae (RD). Asterisks immediately after the higher taxonomic names and arrows on nodes indicate taxa failing to resolve monophyletic assemblages, and species clustered into unrelated groups, respectively. 
neus complex, albeit without good nodal support. The BI tree also failed to resolve monophyletic assemblages of some taxa, such as Awaous, Eviota, Trimma, and Ondontobutidae. Those exceptions aside, the tree largely assigned species to identical major groups.

\section{DISCUSSION}

The COI sequences did resolve genealogical relationships well at the level of genera and family in Gobioidei. As previously noted in Che et al. (2012), this was possibly due to at least two factors. Most likely, the 542 nucleotides do not provide sufficient phylogenetically informative characters to recover the true phylogeny when examining hundreds of taxa with enormous diversity. In addition, the fast mutation rate and saturation in the third codon position can be a disadvantage at deeper phylogenetic levels, and the subsequent long terminal branches may impede resolution of ancient speciation due to the chance accumulation of shared character states (Huelsenbeck, 1997). Despite the poor monophyletic resolution in several taxa, some clear phylogenetic signatures were observed in the COI sequence data. For example, several major congeneric species, Rhinogobius and Bathygobius, tended to cluster together with no exception and, in most cases, so did consubfamilial species. It is believed that the utilization of more gene regions including nuclear DNA will assist in offering a more reliable phylogeny within Gobiidae and their placement within Gobioidei. Several nuclear genes such as recombination activating genes 1 and 2 (Rag 1 and 2 ) and ryandine receptor 3 (Ryr3) may have slower rate of sequence evolution in gobies compared to that of mtDNA genes (Yamada et al., 2009).

Our results support the validity of COI barcoding for species identification in gobiid species, although no attempt was made to include numerous specimens for any one species. One fundamental barcoding criterion is that congeneric divergence should be significantly higher than that of conspecific divergence (Hubert et al., 2008). The average intragenus distance (K2P) for 28 genera with multiple species in the present study was $21.09 \%$, which was considerably higher than the values obtained among fish species in previous studies $(9.93 \%$ from Ward et al., 2005; 9.54\% from Ward and Holmes, 2007). In addition, the interspecific divergence at higher taxonomic levels was not significantly larger than that at the intragenus level, suggesting that congeneric gobies possess substantial interspecific sequence divergence in their COI genes. Significantly more nucleotide changes were observed at the third codon position than those at the first and the second, revealing that the extensive variation shown among the COI sequences typically reflects synonymous changes and little variation at the protein level. Consequently, the proportion of nonsynonymous to synonymous changes was far less than one (Table 2). As previously noted in Ward and Holmes (2007), this result must be due to exceptionally strong purifying selection of the COI gene and confirms that the ability of COI to identify species in Gobiidae is dependent on the degenerate nature of the genetic code.

We did not provide sufficient evidence for the utility of the COI towards cryptic species identification in several species complexes. Gobiidae taxonomy has been studied extensively for the last several decades, but confusion still exists. One typical case is the taxonomic status of the Gymnogobius species complex (G. urotaenia, G. opperiens, and G. petschiliensis) (e.g., Harada et al., 2002). In our results, overall K2P divergence within Gymnogobius was $12.74 \%$, whereas the average value among the Gymnogobius species complex was only $1.81 \%$, probably reflecting a short history of reproductive isolation. The Rhinogobius brunneus complex (in our analysis, Rhinogobius brunneus, R. brunneus CB, and $R$. brunneus $\mathrm{CO}$ ) is also a representative example of a cryptic species complex in Gobiidae (Kawanabe and Mizuno, 1989; Kim, 1995). Overall, K2P divergence within Rhinogobius was $>10 \%$, whereas the average value among the $R$. brunneus complex was just $2 \%$. Although more work needs to be done with multiple specimens, the COI sequence may not be a reliable tool to delineate cryptic and complex species boundaries in the family Gobiidae.

\section{ACKNOWLEDGMENTS}

We thank Mr. Seong Jang Jo and Jin Young Choo for their assistance collecting fish. We also thank Seongjun Park for logistical phylogenetic analyses support. Su Youn Baek provided assistance with the laboratory studies. This study was supported by the grant "Korean Tree of Life, 4th Year: Gobioidei Fishes (No. 211C000068)" funded by the National Institute of Biological Resources, Korean Government and awarded to H. Y. Suk.

\section{REFERENCES}

Akihito A, Iwata T, Kobayashi T, Ikeo K, Imanishi T, Ono H, Umehara Y, Hamamatsu C, Sugiyama K, Ikeda Y, Sakamoto K, Fumihito A, Ohno S, Gojobori T, 2000. Evolutionary aspects of gobioid fishes based upon a phylogenetic analysis of mitochondrial cytochrome b genes. Gene, 259:5-15.

April J, Mayden RL, Hanner RH, Bernatchez L, 2011. Genetic calibration of species diversity among North America's freshwater fishes. Proceedings of the National Academy of Sciences United States of America, 108:10602-10607. 
Aquilino SVL, Tango JM, Fontanilla IKC, Pagulayan RC, Basiao ZU, Ong PS, Quilang JP, 2011. DNA barcoding of the ichthyofauna of Taal Lake, Philippines. Molecular Ecology Resources, 11:612-619.

Aquino LMG, Tango JM, Canoy RJC, Fontanilla IKC, Basiao ZU, Ong PS, Quilang JP, 2011. DNA barcoding of fishes of Laguna de Bay, Philippines. Mitochondrial DNA, 22:143153.

Avise JC, Ellis D, 1986. Mitochondrial DNA and the evolutionary genetics of higher animals. Philosophical Transactions of the Royal Society of London Series B Biological Sciences, 312:325-342.

Brown WM, George M Jr, Wilson AC, 1979. Rapid evolution of animal mitochondrial DNA. Proceedings of the National Academy of Sciences of the United States America, 76:19671971.

Che J, Chen HM, Yang JX, Jin JQ, Jiang K, Yuan ZY, Murphy RW, Zhang YP, 2012. Universal COI primers for DNA barcoding amphibians. Molecular Ecology Resources, 12: 247-258.

Clare EL, Lim BK, Engstrom MD, Eger JL, Hebert PDN, 2007. DNA barcoding of Neotropical bats: species identification and discovery within Guyana. Molecular Ecology Notes, 7: 184-190.

Ebach MC, Holdrege C, 2005. More taxonomy, not DNA barcoding. BioScience, 55:822-823.

Feng Y, Li Q, Kong L, Zheng X, 2011. COI-based DNA barcoding of Arcoida species (Bivalvia: Pteriomorphia) along the coast of China. Molecular Ecology Resources, 11:435-441.

Hall TA, 1999. BioEdit: a user-friendly biological sequence alignment editor and analysis program for Windows 95/98/ NT. Nucleic Acids Symposium Series, 41:95-98.

Harada S, Jeon SR, Kinoshita I, Tanaka M, Nishda M, 2002. Phylogenetic relationships of four species of floating gobies (Gymnogobius) as inferred from partial mitochondrial cytochrome b gene sequences. Ichthyological Research, 49:324332.

Hebert PDN, Cywinska A, Ball SL, DeWaard JR, 2003. Biological identifications through DNA barcodes. Proceedings of the Royal Society B: Biological Sciences, 270:313-321.

Hebert PDN, Stoeckle MY, Zemlak TS, Francis CM, 2004. Identification of birds through DNA barcodes. PLoS Biology, 2:e312.

Herler J, Munday PL, Hernaman V, 2011. Gobies on coral reefs. In: The biology of gobies (Eds., Patzner RA, van Tassell JL, Kovačić M, Kapoor BG). Science Publishers, New York, pp. 493-530.

Hubert N, Hanner R, Holm E, Mandrak NE, Taylor E, Burridge M, Watkinson D, Dumont P, Curry A, Bentzen P, Zhang J, April J, Bernatchez L, 2008. Identifying Canadian freshwater fishes through DNA barcodes. PLoS ONE, 3:e2490.

Hubert N, Meyer CP, Bruggemann HJ, Guérin F, Komeno RJL, Espiau B, Causse R, Williams JT, Planes S, 2012. Cryptic diversity in Indo-Pacific coral-reef fishes revealed by DNAbarcoding provides new support to the centre-of-overlap hypothesis. PLoS ONE, 7:e28987.

Huelsenbeck JP, 1997. Is the Felsenstein zone a fly trap? Systematic Biology, 46:69-74.

Ivanova NV, Zemlak TS, Hanner RH, Hebert PDN, 2007. Universal primer cocktails for fish DNA barcoding. Molecular Ecology Notes, 7:544-548.

Johns GC, Avise JC, 1998. A comparative summary of genetic distances in the vertebrates from the mitochondrial cytochrome b gene. Molecular Biology and Evolution, 15:14811490 .

Kawanabe H, Mizuno N, 1989. Freshwater fishes of Japan. Yamatokeikokusha, Tokyo, pp. 1-719.

Keith P, Lord C, Lorion J, Watanabe S, Tsukamoto K, Couloux A, Dettai A, 2011. Phylogeny and biogeography of Sicydiinae (Teleostei: Gobiidae) inferred from mitochondrial and nuclear genes. Marine Biology, 158:311-326.

Kim JB, 1995. The studies of speciation and systematics on the fishes of the genera Rhinogobius and Tridentiger (Perciformes, Gobiidae) in Korea. $\mathrm{PhD}$ dissertation, Inha University, Incheon, Korea, pp. 1-158.

Kimura M, 1980. A simple method for estimating evolutionary rates of base substitutions through comparative studies of nucleotide sequences. Journal of Molecular Evolution, 16: 111-120.

Larkin MA, Blackshields G, Brown NP, Chenna R, McGettigan PA, McWilliam H, Valentin F, Wallace IM, Wilm A, Lopez R, Thompson JD, Gibson TJ, Higgins DG, 2007. Clustal W and Clustal X version 2.0. Bioinformatics, 23:2947-2948.

Larson HK, 2001. A revision of the gobiid fish genus Mugilogobius (Teleostei: Gobioidei), and its systematic placement. Records of the Western Australian Museum, Supplement 62:1-233.

Leray M, Boehm JT, Mills SC, Meyer CP, 2012. Moorea BIOCODE barcode library as a tool for understanding predatorprey interactions: insights into the diet of common predatory coral reef fishes. Coral Reefs, 31:383-388.

Moore WS, 1995. Inferring phylogenies from mtDNA variation: mitochondrial-gene trees versus nuclear-gene trees. Evolution, 49:718-726.

Murdy EO, 1989. A taxonomic revision and cladistic analysis of the oxudercine gobies (Gobiidae: Oxudercinae). Records of the Australian Museum, Supplement, 11:1-93.

Nei M, Gojobori T, 1986. Simple methods for estimating the numbers of synonymous and nonsynonymous nucleotide substitutions. Molecular Biology and Evolution, 3:418-426.

Nei M, Kumar S, 2000. Molecular evolution and phylogenetics. Oxford University Press, Oxford, pp. 1-352.

Nelson JS, 2006. Fishes of the world. 4th ed. John Wiley and Sons, Hoboken, NJ, pp. 1-601.

Parenti LR, Thomas KR, 1998. Pharyngeal jaw morphology and homology in sicydiine gobies (Teleostei: Gobiidae) and allies. Journal of Morphology, 237:257-274.

Pezold F, 1993. Evidence for a monophyletic Gobiinae. Copeia, 1993:634-643.

Posada D, Crandall KA, 1998. Modeltest: testing the model of 
DNA substitution. Bioinformatics, 14:817-818.

Ronquist F, Huelsenbeck JP, 2003. MRBAYES 3: Bayesian phylogenetic inference under mixed models. Bioinformatics, 19:1572-1574.

Roques S, Fox CJ, Villasana MI, Rico C, 2006. The complete mitochondrial genome of the whiting, Merlangius merlangus and the haddock, Melanogrammus aeglefinus: a detailed genomic comparison among closely related species of the Gadidae family. Gene, 383:12-23.

Steinke D, Zemlak TS, Hebert PDN, 2009. Barcoding nemo: DNA-based identifications for the ornamental fish trade. PLoS ONE, 4:e6300.

Tamura K, Peterson D, Peterson N, Stecher G, Nei M, Kumar S, 2011. MEGA5: Molecular Evolutionary Genetics Analysis using maximum likelihood, evolutionary distance, and maximum parsimony methods. Molecular Biology and Evolution, 28:2731-2739.

Thacker CE, 2003. Molecular phylogeny of the gobioid fishes (Teleostei: Perciformes: Gobioidei). Molecular Phylogenetics and Evolution, 26:354-368.

Thacker CE, 2009. Phylogeny of Gobioidei and placement within Acanthomorpha, with a new classification and investigation of diversification and character evolution. Copeia, 2009: 93-104.

Thacker CE, Hardman MA, 2005. Molecular phylogeny of basal gobioid fishes: Rhyacichthyidae, Odontobutidae, Xenisthmidae, Eleotridae (Teleostei: Perciformes: Gobioidei). Molecular Phylogenetics and Evolution, 37:858-871.

Thacker CE, Schaefer SA, 2000. Phylogeny of the wormfishes (Teleostei: Gobioidei: Microdesmidae). Copeia, 2000:940957.

Thacker CE, Thompson AR, Roje DM, 2011. Phylogeny and evolution of Indo-Pacific shrimp-associated gobies (Gobiiformes: Gobiidae). Molecular Phylogenetics and Evolution, 59:168-176.

Tornabene L, Baldwin C, Weigt LA, Pezold F, 2010. Exploring the diversity of western Atlantic Bathygobius (Teleostei: Gobiidae) with cytochrome c oxidase-I, with descriptions of two new species. Aqua Journal of Ichthyology and Aquatic Biology, 16:141-170.

Triantafyllidis A, Bobori D, Koliamitra C, Gbandi E, Mpanti M, Petriki O, Karaiskou N, 2011. DNA barcoding analysis of fish species diversity in four north Greek lakes. Mitochodrial DNA, 22:37-42.

Wang HY, Tsai MP, Dean J, Lee SC, 2001. Molecular phylogeny of gobioid fishes (Perciformes: Gobioidei) based on mitochondrial 12S rRNA sequences. Molecular Phylogenetics and Evolution, 20:390-408.

Ward RD, Holmes BH, 2007. An analysis of nucleotide and amino acid variability in the barcode region of cytochrome $\mathrm{c}$ oxidase I ( $\operatorname{cox} 1)$ in fishes. Molecular Ecology Notes, 7:899907.

Ward RD, Zemlak TS, Innes BH, Last PR, Hebert PDN, 2005. DNA barcoding Australia's fish species. Philosophical Transactions of the Royal Society of London Series B Biological Sciences, 360:1847-1857.

Weigt LA, Baldwin CC, Driskell A, Smith DG, Ormos A, Reyier EA, 2012. Using DNA barcoding to assess Caribbean reef fish biodiversity: expanding taxonomic and geographic coverage. PLoS ONE, 7:e41059.

Will KW, Mishler BD, Wheeler QD, 2005. The perils of DNA barcoding and the need for integrative taxonomy. Systematic Biology, 54:844-851.

Yamada T, Sugiyama T, Tamaki N, Kawakita A, Kato M, 2009. Adaptive radiation of gobies in the interstitial habitats of gravel beaches accompanied by body elongation and excessive vertebral segmentation. BMC Evolutionary Biology, 9:145.

Zander CD, 2011. Morphological adaptation to special environments of gobies. In: The biology of gobies (Eds., Patzner RA, van Tassell JL, Kovačić M, Kapoor BG). Science Publishers, New York, pp. 345-366.

Received September 23, 2012 Revised October 18, 2012 Accepted October 20, 2012 